\title{
Effects of Pistacia Atlantica Extract on Erythrocyte Membrane Rigidity, Oxidative Stress, and Hepatotoxicity Induced by $\mathrm{CCl}_{4}$ in Rats
}

\author{
Mohsen Tolooei ${ }^{1} \&$ Ali Mirzaei ${ }^{2}$ \\ ${ }^{1}$ Department of biology, Islamic Azad University, Ahar branch, Ahar, Iran \\ ${ }^{2}$ Medicinal Plants Research Center, Yasuj University of Medical Sciences, Yasuj, Iran \\ Correspondence: Ali Mirzaei, Medicinal Plants Research Center, Yasuj University of Medical Sciences, Yasuj, \\ Iran. E-mail: mirzaee3a2003@yahoo.com
}

\author{
Received: November 24, 2014 Accepted: January 28, 2015 Online Published: March 26, 2015 \\ doi:10.5539/gjhs.v7n7p32 \\ URL: http://dx.doi.org/10.5539/gjhs.v7n7p32
}

\begin{abstract}
Background: Previous findings have suggested that antioxidants may reduce the levels of free radicals, which induce oxidative damage and play a key role in various diseases. Thus, we evaluated the protective activity of a Pistacia atlantica extract on erythrocyte membrane rigidity, oxidative stress, and hepatotoxicity induced by carbon tetrachloride $\left(\mathrm{CCl}_{4}\right)$ in rats.
\end{abstract}

Materials and Methods: Fresh leaves of P.atlantica were collected from the mountains in Yasuj, Iran. Acute oral toxicity $\left(\mathrm{LD}_{50}\right)$ was evaluated in Wistar rats $(200-230 \mathrm{~g})$. Animals were randomly divided into 4 groups, out of which the negative and plant control groups received distilled water and $P$. atlantica extracts $(500 \mathrm{mg} / \mathrm{kg})$, respectively. The toxic rat group received $\mathrm{CCl}_{4}$, while the treatment group received $\mathrm{CCl}_{4}+P$. atlantica extract. Blood plasma was utilized for the estimation of enzyme markers and lipid peroxidation, whereas hemolysate was applied for the determination of superoxide dismutase (SOD) and catalase activities. The levels of cholesterol and phospholipids in erythrocyte membranes were also determined. Rats were killed under anesthesia by cervical dislocation; liver was isolated from each rat and tissues homogenization was prepared for biochemical parameters such as malondialdehyde (MDA) and reduced glutathione (GSH) levels.

Results: $\mathrm{LD}_{50}$ values were determined for doses $>3000 \mathrm{mg} / \mathrm{kg}$ (p.o.). The activities of glutamic pyruvate transaminase (GPT), glutamic oxaloacetate transaminase (GOT), alkaline phosphatase (ALP) and GSH in the protected group were significantly $(\mathrm{p}<0.001)$ reduced compared with those of toxic rats. In addition, we observed a decrease in the cholesterol level and an increase in red blood cell membrane phospholipids, SOD, and catalase activities $(\mathrm{p}<0.001)$ in the protected group, as compared with toxic rats. Administration of Pistacia atlantica extract normalized liver tissue MDA level $(\mathrm{p}<0.01)$ when compared to $\mathrm{CCl}_{4}$ treated group.

Conclusion: The P. atlantica extract was able to normalize the levels of biochemical markers, including liver enzyme markers, first-line defense enzymes, and lipid peroxidation markers.

Keywords: antioxidant, Pistacia atlantica, SOD, catalase, liver enzyme, lipid peroxidation

\section{Introduction}

Free radicals attack unsaturated fatty acids within the cell membrane and produce lipid peroxidation, which is responsible for heart disease, stroke, arteriosclerosis, cancer, as well as the aging process (Finkel et al., 2000). In the physiological state, the body is protected from free radical damage by enzymatic defense systems such as super oxide dismutase (SOD) and catalase, and also by non-enzymatic compounds supplied by endogenous antioxidants, including $\beta$-carotene, $\alpha$-tocopherol, vitamin $C$, and uric acid (Ago et al., 2010). However, if the activity of endogenous antioxidant enzymes is insufficient to neutralize the free radicals, oxidative stress increases, resulting in a variety of chronic diseases, including diabetes mellitus, cancer, and cardiovascular disease (Lennon et al., 1991).

In contrast, in the pathological state, for example, in case of oxidative stress and lipid peroxidation, the cholesterol/phospholipid (C/P) ratio rises, resulting in an increase in the asymmetry, rigidity, and microviscosity of the erythrocyte membranes, and therefore a reduction in cell fluidity and deformability (Stubbs \& Smith, 
(1984). The cholesterol and phospholipids in erythrocyte membranes are known to play an important role in membrane function, permeability, fluidity, and cell integrity (Fadeel \& Xue, 2009).

The liver plays a key role in the biosynthetic and metabolic processes of the body. In particular, since the liver is an important organ for detoxification, it may be damaged by carbon tetrachloride $\left(\mathrm{CCl}_{4}\right)$ intoxication. A previous study has shown that hepatic enzyme markers, including glutamic pyruvate transaminase (GPT), glutamic oxaloacetate transaminase (GOT), alkaline phosphatase (ALP), and lipid peroxidation, are increased in response to oxidative stress (Rahman, 2001). Medicinal plants play an important role in the prevention of hepatic diseases. Diverse varieties of the Pistacia genus grow in different provinces in Iran (Valipour, 1995), which is a major source of pistachios, including three basic varieties: Pistacia vera, P. khinjuk, and P. atlantica (Behboodi, 2003).

P. atlantica is considered a beneficial tree since it yields fruits and grows in many regions of Iran, including the Zagros Mountains. The resin and fruit oils of $P$. atlantica have traditionally been used in the treatment of gastrointestinal disorders and throat infections, and may have antibacterial, anti-inflammatory, antiviral, and antipyretic activities (Taran et al., 2010; Nabila et al., 2008). Pistachios are rich in phenolic substances, which are antioxidants that inhibit lipoperoxidation (Nabila et al., 2008). In this study, $\mathrm{CCl}_{4}$ was used to induce erythrocyte and hepatic cell damage (Parola et al., 1992), and hydroalcoholic P. atlantica extract was used to normalize the hepatic cell and erythrocyte cell membrane structures.

\section{Materials and Methods}

\subsection{Plant Samples}

Fresh leaves of P.atlantica were collected from the mountains in Yasuj, Iran.The identification of plant samples was confirmed by a taxonomist at the Department of Botany of Yazd University. Samples were washed, dried in the shade, and ground into a powder.Ground samples were extracted with ethanol $(70 \%)$ and concentrated with a rotary evaporator (Heidolph Laborota 4000, Germany). The crude extract was subsequently concentrated and stored at $-20^{\circ} \mathrm{C}$ until further analysis. A voucher specimen was deposited in the Medical Biochemistry laboratory for future reference (MPRC P.Ch.002/2006).

\subsection{Experimental Design}

This study was carried out on 4 groups of healthy male albino rats. The animals (weighing 200-230 g) were obtained from our rat colony and housed in a well-ventilated animal house at $22 \pm 2{ }^{\circ} \mathrm{C}$ under conditions of 12 -h dark/light cycles. All experimental rats had free access to drinking water and conventional laboratory rat food, supplied by Dam Pars Company, Iran.All animal experiments were performed according to the ethical guidelines of the Institutional Animal Ethics Committee, Iran.

\subsection{Acute Toxicity}

Acute toxicity $\left(\mathrm{LD}_{50}\right)$ was estimated (p.o.) in 21 male rats divided into 7 groups. The rats matched for weight and size, and were fasted for $3 \mathrm{~h}$ before the investigation. The first group served as a control group and received a single dose of $1 \mathrm{ml} / \mathrm{kg}$ distilled water p.o. Groups 2-7 were treated with a single dose of hydroalcoholic $P$. atlantica extract $(500-3000 \mathrm{mg} / \mathrm{kg})$.

Housed animals were constantly inspected for abnormal behavior and symptoms of toxicity for $1 \mathrm{~h}$ after the treatment, and they were sporadically examined every $4 \mathrm{~h}$ for 1 day and every $24 \mathrm{~h}$ thereafter for a period of 14 days (Twaij et al., 1993). All experimental rats had free access to drinking water and standard laboratory rat diets. The $\mathrm{LD}_{50}$ value was determined by the arithmetical procedure of Karber (Turner, 1965).

\subsection{Hepatic Toxicity and Erythrocyte Cell Membrane Studies}

Animals were divided into 4 groups, each containing 6 rats. Distilled water was used as a carrier for the $P$. atlantica extract $\left(0.5 \mathrm{~g} / \mathrm{kg}\right.$ body weight/day p.o.). Olive oil was used as a carrier for $\mathrm{CCl}_{4}(1 \mathrm{ml} / \mathrm{kg}$ body weight p.o.), which was administered 3 times a week for 14 days. The following animal groups were used: group I (negative control), olive oil; group II (extract control), P. atlantica extract + olive oil; group III (toxic group), $\mathrm{CCl}_{4}+$ olive oil p.o.; and group IV (protected group), P. atlantica extract $+\mathrm{CCl}_{4}$ p.o.

All experimental rats were fasted for half a day and anesthetized with diethyl ether. Blood was obtained by heart puncture into tubes containing heparin as an anticoagulant.

Rats were killed under anesthesia by cervical dislocation; liver was isolated from each rat and prepared for tissues homogenization of biochemical parameters such as MDA and GSH levels.

After centrifugation of whole blood at $3000 \mathrm{rpm}$, plasma was collected.The buffy coat was removed, and the packed cells were washed 3 times with saline $(0.9 \% \mathrm{NaCl})$. Packed cells were lysed, using cold distilled water, 
resulting in the formation of a hemolysate. The hemolyzed cells were subsequently centrifuged at $7000 \mathrm{rpm}$ for $30 \mathrm{~min}$ to allow the erythrocyte membranes to settle at the bottom of the tubes.

Plasma was used for GPT, GOT, and ALP, which was analyzed with standard kits from local laboratories in Iran.The results were described in units/liter (U/l). Plasma was also used for the measurement of lipoperoxidation (Gutteridge, 1982), whereas the hemolysate was used to analyze the activities of SOD (Misra \& Fridovich 1972) and catalase (Beers RF \& Sizer., 1952).

Red blood cell membrane lipids were also extracted (Folch et al., 1957), and used to measure the C/P ratio (Searcy \& Bergquist, 1960).For hepatotoxicity evaluation malondialdehyde (MDA) and reduced glutathione (GSH) were estimated in tissues homogenized (Ohkawa et al., 1979; Ellman, 1959).

\subsection{Statistical Analysis}

Comparisons between different groups were performed using analysis of variance (ANOVA) and post-hoc tests. The results were expressed as mean \pm standard deviation (SD). $P$-values less than 0.05 were considered significant.

\section{Results}

No evidence of oral acute toxicity or mortality was observed in the different groups of rats after 14 days, even with the maximum dose of $3000 \mathrm{mg} / \mathrm{kg}$ body weight. Thus, the $\mathrm{LD}_{50}$ of extracts was calculated for doses $>3000$ $\mathrm{mg} / \mathrm{kg}$.

Treatment with the $P$. atlantica extract did not produce significant changes in the enzyme levels compared with the negative control (Table 1). However, there was a significant $(\mathrm{P} \leq 0.05)$ increase, compared with the control group, in the hepatic levels of GPT, GOT, and ALP enzymes following $\mathrm{CCl}_{4}$ administration in toxic rats. Moreover, administration of the $P$. atlantica extract $(500 \mathrm{mg} / \mathrm{ml})$ to the protected group significantly lowered the level of $\mathrm{CCl}_{4}$-induced hepatic enzymes, compared with the toxic group.

Lipid peroxidation in the plasma and liver tissue were increased in rats that received $\mathrm{CCl}_{4}$. However, treatment with an oral dose of $P$. atlantica extract $(500 \mathrm{mg} / \mathrm{kg})$ significantly decreased the lipid peroxidation levels, compared with the control group (Table 2).

Intoxication of rats with $\mathrm{CCl}_{4}$ produced a significant decrease in the hepatic tissue MDA, SOD and catalase activities, whereas the activity of these enzymes increased in the protected group $(\mathrm{P} \leq 0.05)$ (Table 2).

In addition, administration of $\mathrm{CCl}_{4}$ in toxic rats brought about an increase in the level of membrane cholesterol and a reduction in the membrane phospholipids. However, treatment with the $P$. atlantica extract prevented cell membrane changes by decreasing the cholesterol concentration and increasing membrane phospholipid levels (Table 3).

$\mathrm{CCl}_{4}$ treated group had significantly increased MDA and decrease GSH contents $(\mathrm{p}<0.001)$ in liver tissue compare to control group. Administration of Pistacia atlantica extract normalized liver tissue MDA level ( $\mathrm{p}<0$. 01) when compared to $\mathrm{CCl}_{4}$ treated group. However, simultaneous treatment with Pistacia atlantica extract provided a significant increase in liver GSH levels $(\mathrm{p}<0.01)$ (Table 4).

Table 1. Results of Pistacia atlantica extract on Plasma hepatic markers ALT, AST and ALP in rats intoxicated by $\mathrm{CCl}_{4}$

\begin{tabular}{llll}
\hline Group & ALT (U/l) & AST (U/l) & ALP (U/l) \\
\hline I & $70.7 \pm 1.3$ & $58.1 \pm 2.1$ & $71.8 \pm 1.4$ \\
II & $65.3 \pm 1.6$ & $54.1 \pm 1.9$ & $70.6 \pm 1.5$ \\
III & $254 \pm 4.4^{\mathrm{a}}$ & $232.8 \pm 8.5^{\mathrm{a}}$ & $213.3 \pm 9.7^{\mathrm{a}}$ \\
IV & $209.8 \pm 5^{\mathrm{ab}}$ & $211.3 \pm 9.3^{\mathrm{ab}}$ & $171.8 \pm 11^{\mathrm{ab}}$ \\
\hline
\end{tabular}

Values are means \pm standard deviation for six rats per group;

A Statistically significant difference $v s$. Group I $(p<0.001)$.

b Statistically significant difference $v s$. Group III $(p<0.001)$. 
Table 2. Results of Pistacia atlantica extract on red blood cell antioxidant enzymes and lipid peroxidation products in rats intoxicated by $\mathrm{CCl}_{4}$

\begin{tabular}{llll}
\hline Group & $\begin{array}{l}\text { Lipid peroxidation } \\
\times 10^{-6} \text { (units) }\end{array}$ & $\begin{array}{l}\text { Enzyme activities } \\
\text { (units/mg protein) }\end{array}$ & \\
\hline & & SOD & Catalase \\
I & $0.24 \pm 0.03$ & $182.6 \pm 10.5$ & $1.46 \pm 0.14$ \\
II & $0.21 \pm 0.01$ & $185.4 \pm 3.4$ & $1.5 \pm 0.18$ \\
III & $0.51 \pm 0.02^{\mathrm{a}}$ & $73.1 \pm 4^{\mathrm{a}}$ & $.39 \pm .08^{\mathrm{a}}$ \\
IV & $0.40 \pm 0.05^{\mathrm{ab}}$ & $99.5 \pm 8.5^{\mathrm{ab}}$ & $0.78 \pm 0.1^{\mathrm{ab}}$ \\
\hline
\end{tabular}

Values are means \pm standard deviation for six rats per group;

a Statistically significant difference $v s$. Group I $(p<0.001)$.

b Statistically significant difference $v s$. Group III $(p<0.001)$.

Table 3. Results of Pistacia atlantica extract on red blood cell membrane lipids in rats intoxicated by $\mathrm{CCl}_{4}$

\begin{tabular}{llll}
\hline Group & $\begin{array}{l}\text { Cholesterol } \\
(\mathrm{mg} / 100 \mu \mathrm{l})\end{array}$ & $\begin{array}{l}\text { Phospholipid } \\
(\mathrm{mg} / 100 \mu \mathrm{l})\end{array}$ & $\begin{array}{l}\text { Cholesterol } \\
/ \text { Phospholipid }\end{array}$ \\
\hline I & $0.53 \pm 0.01$ & $1.15 \pm 0.02$ & $0.47 \pm 0.02$ \\
II & $0.49 \pm 0.01$ & $1.15 \pm 0.04$ & $0.43 \pm 0.03$ \\
III & $1.09 \pm 0.14^{\mathrm{a}}$ & $0.73 \pm 0.05^{\mathrm{a}}$ & $1.5 \pm 0.06^{\mathrm{a}}$ \\
IV & $0.82 \pm 0.12^{\mathrm{ac}}$ & $0.84 \pm 0.03^{\mathrm{ac}}$ & $0.98 \pm 0.17^{\mathrm{ab}}$ \\
\hline
\end{tabular}

Values are means \pm standard deviation for six rats per group

a Statistically significant difference $v s$. Group I $(p<0.001)$.

b Statistically significant difference $v s$. Group III $(p<0.001)$.

$c$ Statistically significant difference $v s$. Group III $(p<0.01)$.

Table 4. The effects of Pistacia atlantica extract on hepatic MDA and GSH contents in rats intoxicated by $\mathrm{CCl}_{4}$

\begin{tabular}{llll}
\hline Group & $\begin{array}{l}\text { MDA(nmol/ } \\
\text { protein }\end{array}$ & g & $\begin{array}{l}\text { GSH } \quad(\mathrm{nmol} \\
\text { tissue }\end{array}$ \\
\hline I & $63 \pm 3.3$ & $11 \pm 0.2$ \\
II & $59 \pm 4.1$ & $12.6 \pm 1.3$ \\
III & $131 \pm 5.4^{\mathrm{a}}$ & $5.2 \pm 0.6^{\mathrm{a}}$ \\
IV & $89.2 \pm 6.3^{\mathrm{ac}}$ & $9.9 \pm 0.67^{\mathrm{ab}}$ \\
\hline
\end{tabular}

Values are means \pm standard deviation for six rats per group;

a Statistically significant difference $v s$. Group I $(p<0.001)$.

b Statistically significant difference $v s$. Group III $(p<0.001)$.

$c$ Statistically significant difference $v s$. Group III $(p<0.01)$.

MDA: Malondialdehyde, GSH: reduced glutathione.

\section{Discussion}

This study demonstrated the effectiveness of $P$. atlantica extract against oxidative stress, erythrocyte membrane rigidity, and hepatotoxicity.LD50 of the hydro-alcoholic extract of the $P$. atlantica was found to be greater than $3000 \mathrm{mg} / \mathrm{kg}$, which may be accepted as safe . Thus, the $P$. atlantica extract could be considered safe and non-toxic (OECD, 2001). 
Lipid peroxidation in the physiological state in cells and tissues is low, however, increases in response to oxidative stress due to cell damage. Moreover, the levels of first-line defense antioxidant enzymes, including catalase and SOD, are normally decreased by oxidative stress.

Trichloromethyl as a peroxyl radicals, peroxidation of lipids, tissue damage, and liver injury were produced in hepatotoxic rats which treated with $\mathrm{CCL}_{4}$ (Lee, 2004). In addition, the liver marker enzyme, including GPT, GOT, ALP and MDA level has been shown to increase under conditions of hepatotoxicity, which may be followed by hyperbilirubinemia in severe cases (Rahman et al., 2001).

Furthermore, treatment with the P. atlantica extract decreased the activities of serum enzymes and MDA marker, indicating that this extract could normalize liver function.

The findings of the current study also confirmed $\mathrm{CCl}_{4}$-induced damage to red blood cells, which was demonstrated by the elevation of lipid peroxidation products, decreased catalase and SOD activities. and by the decreased fluidity of erythrocyte membranes.

Moreover, our study confirmed previously published results (Ojo et al., 2006) and showed that administration of the $P$. atlantica extract reduces lipid peroxidation and protects red blood cells against $\mathrm{CCl}_{4}$-induced damage.

SOD is a primary intracellular antioxidant enzyme that protects tissues and reduces cell damage induced by superoxide radicals. In addition, catalase is a hemoprotein antioxidant enzyme that rapidly converts superoxide radicals into water (Otitoju \& Onwurah, 2006). The decrease in SOD and catalase activities, as well as elevated lipid peroxidation in $\mathrm{CCl}_{4}$-intoxicated rats may result from oxidative stress and/or decreased antioxidant defense (Mahdi et al., 1996).

Furthermore, this study revealed that $P$. atlantica extracts are able to improve free radical scavenging activity, resulting in increased SOD, catalase activities and reduced glutathione level and normalized of lipid peroxidation.

Glutathione is an antioxidant indicator with protective function in the metabolism of many toxic agents. It acts as a free radical scavenging agent and conserves cytochrome P-450 by inhibited of lipid peroxidation (Yuan et al., 2008).

In this research, $P$. atlantica extract significantly increased and maintain the liver GSH potential when compared to CCl4- treated rats group. The mechanism of protection by $P$. atlantica extract against $\mathrm{CCl} 4$ toxicity may be due to restoration of the GSH content.

Lipid peroxidation is one of the most important outcomes of free-radical damage to tissues. Peroxidation of fatty acyl groups generally occurs in membrane phospholipids and may change the physicochemical characteristics of membrane lipid bilayers (Lee, 2004). The findings of the present study showed that treatment of rats with $\mathrm{CCl}_{4}$ induced peroxidation of red blood cells, which may have resulted in hemolytic changes. We also observed a positive correlation between membrane oxidation and the C/P ratio (McConnell \& Hubbell, 1971).

However, treatment of experimental animals with the $P$. atlantica extract prevented the alteration of membrane fluidity and decreased the $\mathrm{C} / \mathrm{P}$ ratio. Thus, the $P$. atlantica extract participated in peroxidation by inhibiting free-radical damage to biological membranes (Cooper et al., 1977).

In this study, a similar pattern was observed in the activity of enzymes and lipid peroxidation in rats. Moreover, the reversal in enzyme liver marker activity after treatment with the $P$. atlantica extract may have resulted from decreased oxidative levels. The $P$. atlantica extract may be able to directly neutralize reactive oxygen metabolites because of the presence of different antioxidant substances or increase the synthesis of antioxidant molecules/enzymes, which revealed by increased in reduced glutathione level in rats (Gupta et al., 2002).

Application of $P$. atlantica in traditional medicine for the treatment of jaundice and hypertension may be due to its antioxidant activity (Bentley \& Trimen, 1980). The hepatotoprotective potential of the $P$. atlantica extract may result from its antioxidant property (Gutteridge, 1982) and its ability to stabilize membranes (Meena et al., 2008) by inhibited of lipid peroxidation (Nabila et al., 2008).

\section{Conclusion}

Treatment with a $P$. atlantica extract normalized the levels of biochemical markers. In particular, P. atlantica demonstrated hepatoprotective activity by protecting against hepatic injury produced by $\mathrm{CCl}_{4}$. It is likely that the efficacy of $P$. atlantica is due to its ability to inhibit free radicals.

\section{Acknowledgments}

The authors are grateful to the Yasuj Medicinal Plant Research Center for providing grants and supporting this 
study.

\section{Conflict of Interest}

The authors declare that they have no conflict of interest.

\section{References}

Ago, T., Matsushima, S., Kuroda, J., Zablocki1, D., Kitazono, T., \& Sadoshima, J. (2010). The NADPH oxidase Nox4 and aging in the heart. Aging, 2(12), 1012-1016.

Beers, R. F., \& Sizer, I. W. A. (1952). Spectrophotometric Method for Measuring the Breakdown of Hydrogen Peroxide by Catalase. J. Biol. Chem., 195, 130-140.

Behboodi, B. S. H. (2003). Ecological distribution study of wild pistachios for selection of rootstock. Options Mediterraneennes, 63, 61-67.

Bentley, R. Y., \& Trimen, H. (1980). Medicinal plants. In Gardeli et al. (Eds.), Essential oil composition of Pistacia lentiscus L. and Myrtuscommunis L.: Evaluation of antioxidant capacity of methanolic extracts. Food Chem., 1-11.

Cooper, R. A., Durocher, J. R., \& Leslie, M. H. (1977). Decreased fluidity of red cell membrane lipids in abeta lipoproteinemia. J. Clin. Invest., 60, 115-121. http://dx.doi.org/10.1172/JCI108747

Ellman, G. (1995). Tissue sulphydryl groups. Arch Biochem Biophys, 82, 70-77. http://dx.doi.org/10.1016/0003-9861(59)90090-6

Fadeel, B., \& Xue, D. (2009). The ins and outs of phospholipid asymmetry in the plasma membrane roles in health and disease. Critical Reviews In Biochemistry \& Molecular Biology, 44, 264-277. http://dx.doi.org/10.1080/10409230903193307

Finkel, T., \& Holbook, N. J. (2000). Oxidants, oxidative stress and the biology of ageing. Nature, 408, 239-247. http://dx.doi.org/10.1038/35041687

Folch, J., Lees, M., \& Stanley, G. H. S. (1957). A Simple Method for the Isolation and Purification of Total Lipids from animal Tissues. J. Biol. Chem. 226, 497-509.

Gupta, S. K., Prakash, J., \& Srivastava, S. (2002) .Validation of traditional claim of Tulsi, Ocimum sanctum Linn. as medicinal plant. Indian Journal of Experimental Biology, 40, 765-773.

Gutteridge, J. M. C., \& Wilkins, C. (1982). Copper-dependent Hydroxyl Radical Damage to Ascorbic Acid. Formation of a Thiobarbituric Acid Reactive Product. FEBS. Letters, 137, 327-340. http://dx.doi.org/10.1016/0014-5793(82)80377-3

Lee, E., Woo, C.Y., Choi, D .W., Shin, D., Lee, G., \& You, H. J. (2004) .protective effect of acetoside on CCL $_{4}$ induced hepatotoxicity. Life Sci., 74, 1051-1064. http://dx.doi.org/10.1016/j.lfs.2003.07.020

Lennon, S., Martin, S., \& Cotter, T. (1991). Dose-dependent induction of apoptosis in human tumour cell lines by widely diverging stimuli. Cell Proliferation, 24(2), 203-214. http://dx.doi.org/10.1111/j.1365-2184.1991.tb01150.x

Mahdi, A. A., Singh, R., \& Singh, R. K. (1996) . Role of reactive oxygen species and antioxidants in human disease. In V. Rai, M. L. Nait, \& C. Monoharacharry (Eds), An Overview of Perpectives in Biology (pp. 55-70). Ranpur: World Laser Graphics.

McConnell, H. M., \& Hubbell, W. L. (1971) .Molecular motion in spinlabelled phospholipids and biomembranes. J. Am. Chem. Soc., 93, 314-326. http://dx.doi.org/10.1021/ja00731a005

Meena, B., Ezhilan, R.A., Rajesh, R., Hussain, K.S., Ganesan, B., \& Anandan, R. (2008) . Antihepatotoxic potential of Sargassum polycystum (Phaeophyceae) on antioxidant defense status in Dgalactosamine-induced hepatitis in rats. African J Biochem Res, 2, 51-55.

Misra, H. P., \& Fridovich, I. (1972) .The Role of Superoxide Ion in the Anti-oxidation of epinephrine and a Simple Assay for Superoxide Dismutase. J. Biol. Chem. 247, 3170-3175.

Nabila, B., Fawzia, A. B., \& Tatjana, K. P. (2008). Antioxidant and antimicrobial activities of the Pistacia lentiscus and PAextracts. African Journal of Pharmacy and Pharmacology, 2, 22-28.

OECD. (2001). Acute Oral Toxicity-up and down procedure, Guidelines for testing of chemicals, 425, 1-26.

Ohkawa, H., Ohishi, N., Yagi, K. (1979). Assay for lipid peroxides in animal tissues by thiobarbituric acid reaction. Anal Biochem, 95, 351-358. http://dx.doi.org/10.1016/0003-2697(79)90738-3 
Ojo, O. O., Kabutu, F. R., Bello, M., \& Babayo, U. (2006). Inhibition of paracetamol-induced oxidative stress in rats by extracts of lemongrass (Cymbropogon citratus) and green tea (Camellia sinensis) in rats. African Journal of Biotechnology, 5, 1227-1232.

Otitoju, O., \& Onwurah, I. N. E. (2006). Effects of Rambo insect powder on glutathione-Stransferase (GST) and superoxide dismutase (SOD) activity in rats. Bio. Reourc, 4, 51-58.

Parola, M., Leonarduzzi, G., Biasi, F., Albano, M., Biocca, E., Polic, G., \& Dianzani, M. U. (1992). Vitamin E dietary supplementation protects against $\mathrm{CCl}$ induced chronic liver damage and cirrhosis. Hepatology, 16, 1014-21. http://dx.doi.org/10.1002/hep.1840160426

Rahman, M. F., Siddiqui, M. K., \& Jamil, K. (2001). Effects of Vepacide (Azadirachta indica) on aspartate and alanine aminotransferase profiles in a sub chronic study with rats. Journal of Human and Experimental Toxicology, 20, 243-249. http://dx.doi.org/10.1191/096032701678227730

Rahman, M. F., Siddiqui, M. K., \& Jamil, K. (2001). Effects of Vepacide (Azadirachta indica) on aspartate and alanine aminotransferase profiles in a sub chronic study with rats. Journal of Human and Experimental Toxicology, 20, 243-249. http://dx.doi.org/10.1191/096032701678227730

Searcy, R. L., \& Bergquist, A. (1960). New colour reaction for the quantitation of sereum cholesterol. Clin. Chem. Acta. 5, 192-199. http://dx.doi.org/10.1016/0009-8981(60)90035-8

Stubbs, C. D., \& Smith, A. D (1984).The modification of mammalian membrane polyunsaturated fatty acid composition in relation to membrane fluidity and function. Biochimica et Biophysica Acta, 779, 89-137. http://dx.doi.org/10.1016/0304-4157(84)90005-4

Taran, M., Sharifi, M., Azizi, E., \& Khanahmadi, M. (2010). Antimicrobial Activity of the Leaves of Pistacia khinjuk. Journal of Medicinal Plants, 9, 81-85.

Turner, R. (1965). Quantal responses. Calculation of LD50 In Screening Methods in Pharmacology (pp. 61-63). Academic Press, New York.

Twaij, H. A. A., Kery, A., \& Al Khazraji, N. K. (1983). Some pharmacological, toxicological and phytochemical investigations on Centaurea phyllocephala. Journal of Ethnopharmacology. 9, 299-314. http://dx.doi.org/10.1016/0378-8741(83)90037-5

Valipour, P. (1995). Economical investigation of wild pistachio.The first national seminar of wild pistachio (Green Pearl). Ilam Research Center of National Resources and Animal Consumptions. 4 and 5 November.

Yuan, L. P., Chen, F. H., Ling, L., Bo, H., Chen, Z. W., Li, F., Zhong, M. M., \& Xia, L. J. (2008). Protective effects of total flavonoids of Bidens bipinnata L. against carbon tetrachloride-induced liver fibrosis in rats. $J$. Pharm. Pharmacol., 60(10), 1393-1402. http://dx.doi.org/10.1211/jpp.60.10.0016

\section{Copyrights}

Copyright for this article is retained by the author(s), with first publication rights granted to the journal.

This is an open-access article distributed under the terms and conditions of the Creative Commons Attribution license (http://creativecommons.org/licenses/by/3.0/). 